\title{
WG4：被災地周辺の交通，物流分析
}

Transportation and Logistics Analysis

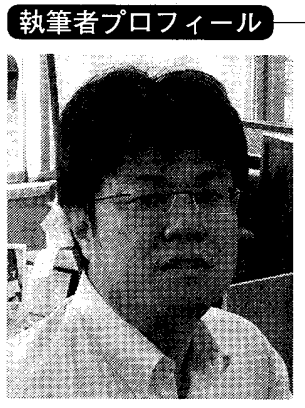

東日本大震災調查・提言

分科会 WG4 主查

鎌田 崇義

Takayoshi KAMADA

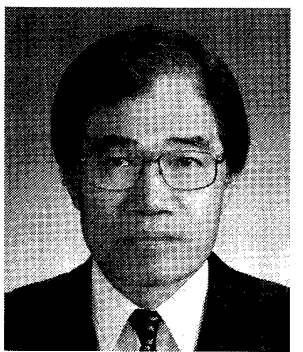

(2)1972 年東京大学工学部機械工学科卒業, 1977 年東京大学工学系研究科産業機械工学 専攻博士課程修了, 工学博士, 1977 年より 現職

()研究・尃門テーマは, 車両工学, 機械力学 · 制御

○正員 (フェロー), 東京農工大学教授 工学 府機械システム工学專攻

（T184-8588 東京都小金井市中町 2-24-16 E-mail : nagai@cc.tuat.ac.jp)

東日本大震災調查・提言

分科会 WG4 前主查

永井 正夫

Masao NAGAI
○1989 年東京大学工学部機械工学科卒業, 1994 年東京大学工学系研究科产業機械工学 1998 年東京大学助手生産技術, 研究所 1998 年より現職

御、スマート構造

正員, 東京農工大学教授 エ学府機械システ 少学尃攻

(T184-8588 東京都小金井市中町 2-24-16 E-mail : kama@cc.tuat.ac.jp)

\section{1。 はじめに}

本稿は東日本大震災調査・提言分科会のWG4 で行った 被災地周辺の交通・物流分析について報告したものである.

\section{2. 被害の概況}

東北地方の広い地域で交通，物流手段に被害が出たこと は改めて言うまでもない. 工業製品を作る過程で，アッセ ンブリを行う工場に被害がなくても，多数の部品工場が被 害を受けた，交通が途切れて輸送ができなくなった等で， 製品供給が滞ったケースも多々あった。

陸海空の交通手段に関しては，津波の被害を受けた仙台 空港では，幸いすべての離陸予定機は仙台空港を離陸済み であったため，人的な被害はなかった。また，海上でも夕 ンカーの被害による大規模火災や重油の流出等は起こらな かった。これらに比べ，陸の交通手段である鉄道，自動車 等は東北の広い地域でダメージを受けた。

\section{3. 鉄道における被災の状況}

鉄道に扔いては図1に示すような津波による車両の被 害だけでなく，図 $2^{(1)} に$ 示すように駅建物，線路，架線， 柱や橋といったインフラが広範囲で大きな被害を被った。 海岸沿いを走る路線では地震と津波両方の被害を受けたと ころも少なくないが, 新幹線においては津波の被害は受け なかった。また，土木・建築的な被害に比べれば機械的な 被害はそれほど大きなものではなかった．太平洋沿いを走 る路線では， 27 編成の車両が駅間で停止したが，速やか に避難対応がとられ，5編成が津波にさらわれたものの， 乗客はすべて避難済みであり人的な被害はなかった。人命 優先の正しい判断がとられたものと評価できる。

東北新幹線では地震発生時, 18 編成が通常運転中であ り，時速 270 キ口前後で走行していた車両もあったが，す べての編成が脱線することなく速やかに停止し, 乗客に被 害者も出なかった。これは $\mathrm{P}$ 波と呼ばれる地震初期の小 さな摇れを感知し, $\mathrm{S}$ 波と呼ばれる主要な摇れが来る前に 列車を停止させるシステムのおかげであった。この早期地 震検知警報システム（地震動早期検知警報システム）は通 称 UrEDAS（ユレダス）と呼ばれ，1989年に東海道新幹 線に導入された。 その後, 兵庫県南部地震, 中越地震等の 大地震での経験をもとに，現在は $\mathrm{P}$ 波検知から警報発生 までの時間が大幅に短縮されたコンパクトユレダス, FREQL (フレックル), TERRA-S (テラス) が開発され, 在来線や東京メトロでも導入されている.

さらに, 中越地震以降, 仮に新幹線が脱線した場合でも 軌道から大きく外れて転倒してしまうことを機械的に防止 するシステムも開発され，実用化に至っている。

首都圈でも被害が確認されている。JRでは山手線，中 央線, 京浜東北線といった主要路線において, 軌道変状や 架線故障等, 運転が不可能となるような被害が発生した。 また, 駅においても図 3 に示すような天井破損やひび割れ， 水漏れなどの非構造部材の被害が確認されている.

\section{4. 自動車交通における被災の状況}

自動車交通においては地震と津波によって多くの道路や 信号機が被害を受けた。ささらに，津波によって流されてし まった車両も多数あった. 自動車は移動手段としてだけで なく，暖をとるための手段としても活用されたが，ガソリ ンスタンドも被害を受けたため, 然料不足によって多くの 車は使用することができなかった。

交通に関しては Google（株）が震災三日後の3月14日 から本田技研工業（株），パイオ二ア（株）の協力のもと， カーナビ情報を利用して被贸地の自動車通行実績のネット 公開を開始した。2012 年3月現在，渋滞情報を合わせた 形で表示サービスを続けている。 さらに，3月19日から4 月 28 日までは特定非営利活動法人である ITS Japan が本田 技研工業, パイオニア, トヨ夕自動車 (株), 日産自動車 (株) からの情報をもとにした通行実績に，国土地理院からの通 行止め情報を合わせた形で図 $4^{(2)}$ に示すような情報提供を 


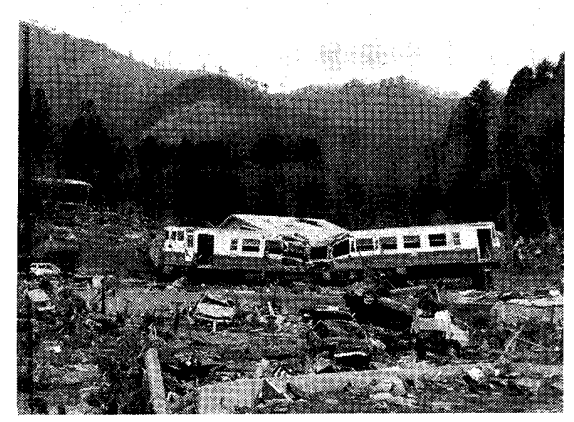

図1 津波による車両の被害 （石巻線女川駅，JR 東日本提供）

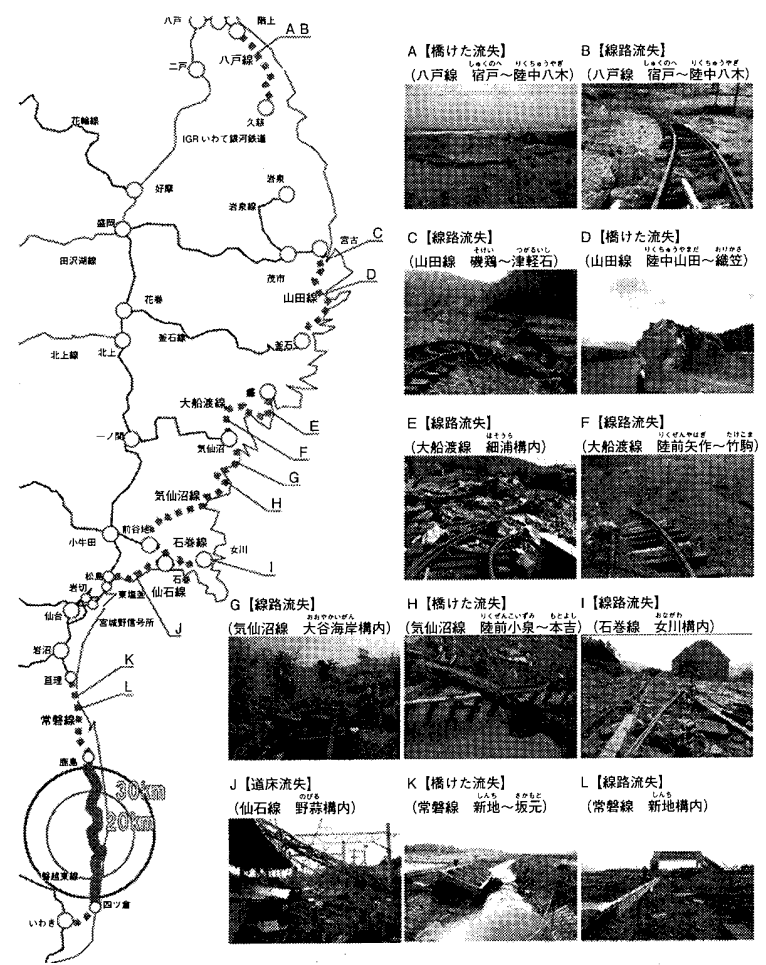

（a）太平洋沿いを走る路線の被害

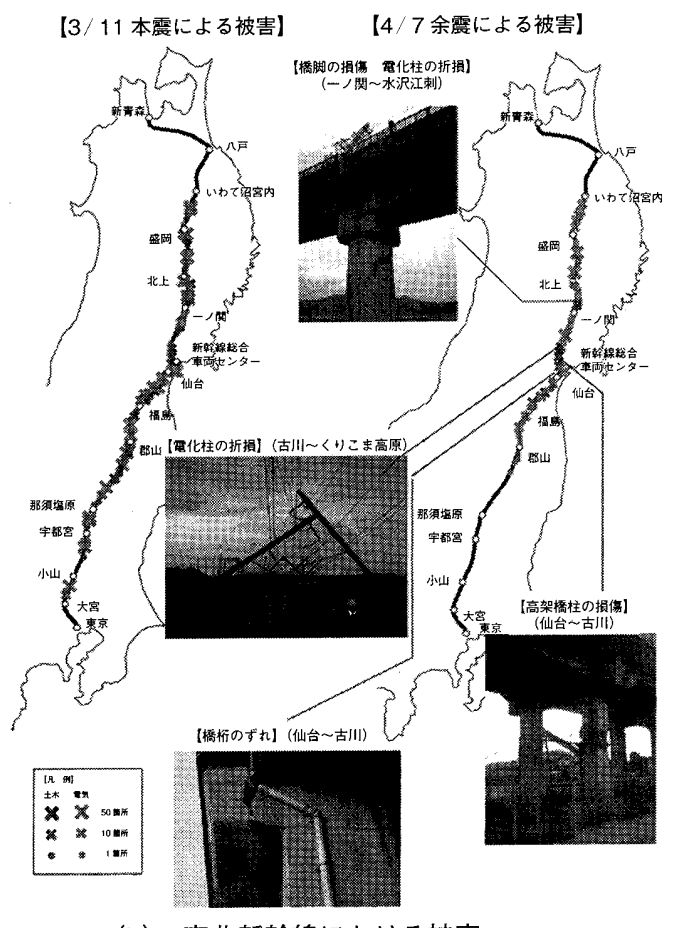

(b) 東北新幹線における被害

図 2 地震と津波による東北地方の鉄道の被害

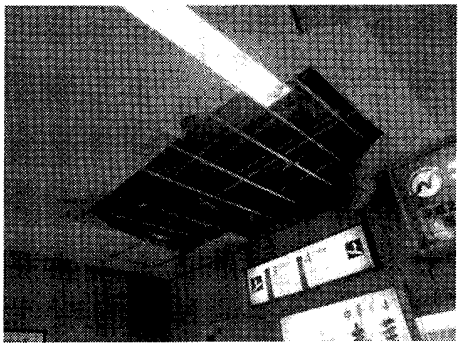

図 3 駅での天井破損 （JR 東日本提供）

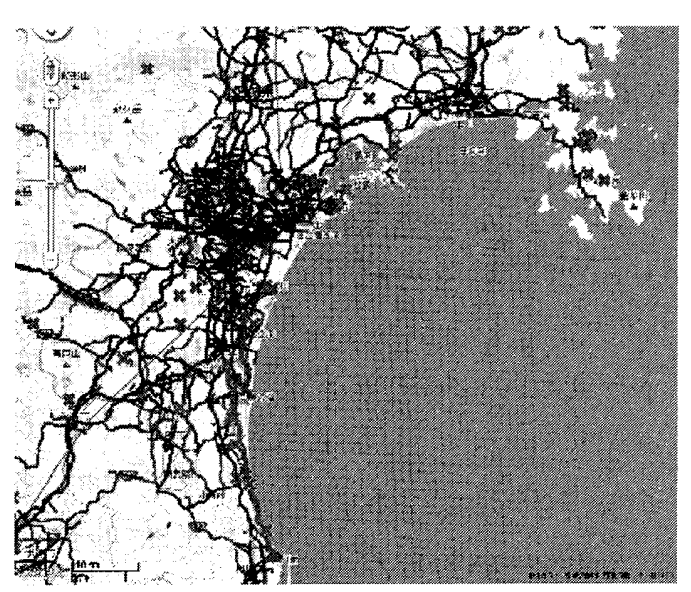

図 4 自動車通行実績情報（ITS Japan 2011.4.13）
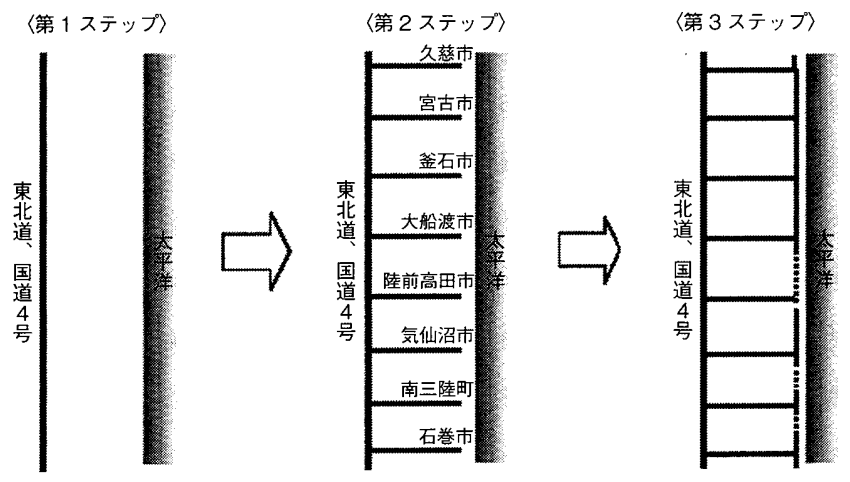

図 5 くしの歯作戦概念図

行っていた. 大型車に関しても, 3 月 25 日からマピオン (株) がいすぶ自動車（株）から提供されたデー夕をもとに $4 \mathrm{t}$ 以上の大中型トラックと小型トラックに分けて通行実績の 提示サービスを行っている.

被害を受けた道路の復興に関しては，国土交通省の打ち 出した“くしの歯作戦”が効果的であった。これは図 5 (3) に示すように，東北道，国道 4 号から津波被害で大きな被 害が想定される沿岸部の国道 6 号, 45 号へ展開する作戦 であり，第 1 ステップとして，東北道，国道 4 号の縦軸ラ インを確保し，その後第 2 ステップで三陸地区へのアクセ スとして東北道, 国道 4 号からの横軸ラインを確保, 最後 に沿岸側の縦のラインを復旧することによって，国道 45 号では，3月 18 日までに $97 \%$ が通行可能となる等, 地震 後わずか 1 週間で道路の障害物等は取り除かれて通行可能 になっていた。

\section{5. おわりに}

以上，交通，物流の分野においては，被害は出たものの 過去の震災での教訓を活かした形での対策，復興がなされ たケースも多かった。

たたし，現在懸念されている首都直下型地震では $\mathrm{P}$ 波 と S 波の到着時間の差が小さくなるため, このような場 合においても列車を安全に停止させることができるかどう かは, 重要な課題となっている。また, 首都圏では鉄道の 連休により多くの帰宅困難者を出しており,このような事 態に対する対策も今後検討が必要である。

(原稿受付 2012 年 3 月 21 日)

文 献

(1) 東日本旅客鉄道ホームページ, http://www.jreast.co.jp/press/ earthquake/index.html

(2) ITS Japan ホームページ, http://www.its-jp.org/saigai/

（3）国土交通省 東北地方整備局ホームページ, http://www.thr.mlit. go.jp/ 